\title{
EFFECT OF TWO ENTOMOPATHOGENIC FUNGI IN CONTROLLING Aleurodicus cocois (CURTIS, 1846) (HEMIPTERA: ALEYRODIDAE)
}

\author{
Elizabeth Núñez del Prado ${ }^{1,3}$, José Iannacone ${ }^{1,2}$ *, and Hilda Gómez ${ }^{3}$
}

\begin{abstract}
A B S T R A C T
Aleurodicus cocois (Curtis, 1846), the coconut whitefly, is a very damaging pest in Peru, mainly in avocado trees (Persea americana Mill.). It has been determined that entomopathogenic fungi can infect and kill white flies and can be used as biological control agents. The object of this research was to determine if there is any synergic action of the entomopathogenic fungi Paecilomyces fumosoroseus (Wize) Brown \& Smith 1957 and Verticillium lecanii (Zimmerman, 1892) Viégas 1939, in controlling A. cocois. Plastic sterile dishes were prepared where $5 \mathrm{~mL} 2 \%$ agar were used for each stage; leaves infested with $A$. cocois were placed upon these. Three different treatments were applied by sprinkling: P. fumosoroseus $(\mathrm{P}), V$. lecanii $(\mathrm{V})$ or the mixture of the two fungi. These treatments were evaluated at one, two and seven days in the case of nymph I and eggs, and after four, eight and 12 days for nymph II, NIII and NIV. The lethal effect of $V$. lecanii on the second nymph instar of $A$. cocois was better than that of $P$. fumosoroseus and than the mixture of both fungi; the highest mortality percentage appeared from day eight to day 12. A small increase was observed in the effect of the mixture of the two entomopathogenic fungi on the IV nymph instar, and the effect of P. fumosoroseus was the lowest.
\end{abstract}

Key words: biocontrol, Paecilomyces, pest, Verticillium, white flies.

\section{INTRODUCTION}

Peru is one of five countries of the world which have the highest biological diversity: the fauna in general and the Aleyrodidae (Hemiptera) family are very well represented. The species of this family were not primary pests as a rule, in spite of occasional outbreaks, such as that of the citrus woolly whitefly Aleurothrixus floccosus Maskell 1895, in 1954, 1962 and 1967 (Soto and García, 2002), the cotton whitefly Bemisia tuberculata Bondar 1929 (1956, 1962, 1970 and 1988; Blatta, 2001), the tobacco whitefly Bemisia tabaci Gennadius 1889 (1989, 1995, 1997-98; Blatta, 2001) and the giant fruit fly, also called coconut whitefly (1984 and 1997-1998; Núñez, 1998). During the past 20 years, they have become key pests in some crops, and from 1994 crops of great economic importance such as market-garden produce, cucurbitaceae, leguminoseae, cotton, rice and fruit have been severely attacked by whiteflies (Nuñez, 1995; 2000). Valencia (2000) points out that monoculture covering large surfaces, the capacity of the Geminiviridae family to transmit viruses and the excessive use of organosynthetic pesticides have largely contributed to the growing effect of whiteflies upon several Peruvian crops.

The giant fruit whitefly or coconut whitefly is a very damaging pest in Peru both to fruit trees and ornamental plants (Valencia et al., 2000). It mainly at-

\footnotetext{
${ }^{1}$ Universidad Nacional Federico Villarreal (UNFV), Facultad de Ciencias Naturales y Matemática, Calle San Marcos 383, Pueblo Libre, Lima, Perú. E-mail: joseiannacone@gmail.com *Corresponding author.

${ }^{2}$ Universidad Ricardo Palma (URP), Facultad de Ciencias Biológicas, Av. Benavides 5440, Surco, Lima, Perú.

E-mail: joseiannacone@gmail.com *Corresponding author.

${ }^{3}$ Programa Nacional de Control Biológico del Servicio Nacional de Sanidad Agraria (PNCB-SENASA), Lima, Perú.

Received: 16 March $2007 . \quad$ Accepted: 22 May 2007.
} 
tacks avocado plantations and has become the second pest in economic importance in the country, after $B$. tabaci (Gómez et al., 2000). The main hosts of $A$. cocois in Peru are: mango (Mangifera indica L.), bananas (Musa balbisiana Colla), vines (Vitis vinifera L.), Brazilian pepper tree o molle de la costa (Schinus terebinthifolius Raddi), ficus (Ficus nitida Thunb.) and eucalyptus (Eucalyptus spp.). (Duke, 1983; Morton, 1987; Reátegui and Núñez, 1998; Valencia, 2000; Liceras and Clemente, 2006; Evans, 2007). During severe outbreaks, the characteristic whitish secretion can cover the whole underside of the leaves, as happens in mangoes and Brazilian pepper trees. The damage has reached economic importance in pecans (Carya illinoinensis (Wangenh.) K. Koch) and vines (at Ica, 12 ${ }^{\circ} 12^{\prime}$ to $13^{\circ} 35^{\prime} \mathrm{S} ; 75^{\circ} 20^{\prime}$ to $76^{\circ} 12^{\prime} \mathrm{W}$, Peru) and mangoes (at Ica and Piura, $4^{\circ}$ and $6^{\circ} \mathrm{S} ; 79^{\circ}$ and $81^{\circ} \mathrm{W}$, Peru). The most heavily attacked ornamental species are the Brazilian pepper tree, mulberry (Morus alba L.) and eucalyptus (Valencia, 2000). This insect is present along the whole coast and part of the forest of Peru, especially in Iquitos (Valencia, 2000; Valencia et al., 2000). Morton (1987) and Valencia (2000) mention its presence in the Caribbean, Center and South America. Unfortunately, and in spite of the great economic importance it has reached in time, $A$. cocois is not a widely researched species and little is known about the best control strategies.

Many fungi affect the whitefly complex, the most important are the genera Verticillium, Paecilomyces and Aschersonia. It has also been determined that the entomopathogenic fungi, especially deuteromicetes, can infect and kill all whitefly stages, and therefore could be used as biological control agents. Deuteromicetes are characterized by reproducing mainly by asexual spores (conidia). One of the great advantages of deuteromicetes is that they can be cultured very easily in artificial media, even in easy to obtain and low cost oligidic media. Therefore, they are one of the groups with greater potential as biological control agents in Integrated Pest Control programs.

Paecilomyces fumosoroseus has been recognized for over 20 years as one of the most important biocontrol agents against aleirodids pests in field and greenhouse crops (Valencia, 2000). The fungi cover the dead bodies with slight mycelia threads and stick them to the underside of the leaves. The nymphs show a "feathery" aspect and are surrounded by mycelia and conidia (Shannon, 1996). The Paecilomyces has a great potential for the control of whitefly, and causes the sickness called "Yellow Muscardine" (Nuñez, 1995). The study of $P$. fumororoseus as control agent is important as it is very effective in nature, it grows extensively on the leaves with great ease in humid conditions, therefore multiplies very quickly upon the whitefly population.

On the other hand, Verticillium lecanii is a wide spectrum entomopathogenic fungus (Rodríguez Dos Santos and Del Pozo Núñez, 2003). It can be seen on nymphs and adults, stuck to the leaf underside by means of a filamentous and somewhat crystalline mycelium (Shannon, 1996). V. lecanii is a widely distributed fungus, which can cause large epizootia in tropical and subtropical regions, as well as in warn and humid environments (García and López, 1997).

It has often been verified that the joint action of different entomopathogenic organisms results in a synergic effect (Cloyd, 2001; Zurek et al., 2002). As is the case of the entomopathogenic fungus Beauveria bassiana (Balsam) Vuillemin, 1912, and the bacterium Bacillus thuringiensis var. tenebrionis Bonnefoi \& de Barjac, 1963, for the control of Leptinotarsa decemlineata Say 1823 (Glare and O'Callaghan, 2000; Solter and Wraight, 2001), or additive as is the case of Bacillus thuringiensis var. israelensis de Barjac, 1978, with B. thuringiensis var. kurstaki de Barjac \& Lemille, 1970, for the control of Premnotrypes suturicallus Kuschel, 1956 (Glare and O'Callaghan, 2000). Therefore, in many cases it has been considered advantageous to apply a combination of organisms, which has been shown to be economically advisable as control becomes much more effective (Cloyd, 2001).

The objective of the present research was to assess the mortality caused by the entomopathogenic fungi $P$. fumosoroseus and $V$. lecanii, both singly and combined, on the different stages of A.cocois in laboratory conditions.

\section{MATERIALS AND METHODS}

This research was carried out in the Bioassays and Inoculated Insects environment of the Entomopathogens Laboratory belonging to the National Biological Control Program of the National Agrarian 
Health Service (PNCB-SENASA), Ate Vitarte, Lima, Peru. The present study is a probabilistic (aleatory) sampling, experimental and on a linear time variable.

\section{Establishment of the $A$. cocois breeding}

About 150 to $200 \mathrm{~A}$. cocois adult specimens were collected from eucalyptus trees around the fields of PNCB-SENASA $\left(12^{\circ} 02^{\prime} \mathrm{S} ; 77^{\circ} 01^{\prime} \mathrm{W}\right)$, with the help of a plastic tube, $15 \mathrm{~cm}$ long and $2 \mathrm{~cm}$ in diameter and a thin brush. In order to recognize stages and periods of the $A$.cocois life cycle and assure a source of specimens for the assays, it was established a rearing area with four $1 \mathrm{~m}^{3}$ cages covered with anti-aphid net, each containing 10 Brazilian pepper tree plants, $90 \mathrm{~cm}$ high. 150 to 200 adult $A$. cocois specimens were placed in each cage, until the time that eggs were laid on the leaves. On the day following the infestation, colored tags were placed upon the leaves with freshly laid eggs, using a different color for each oviposition date. After assessment of these results to increase the population, adult specimens were collected from leaves of Brazilian pepper trees at the Magdalena del Mar District, Lima, Peru.

The II instar of the nymph was inoculated four months afterwards. To this end, 150 to 200 adult whitefly specimens were collected from the cages, with the help of a plastic tube and a brush. The collected specimens were employed for infestations every 15 days. Two $S$. terebinthefolius plants, approximately $35 \mathrm{~cm}$ high, were placed in each of five acrylic cages, $36 \times 32 \times 39 \mathrm{~cm}$, with $24 \times 10 \mathrm{~cm}$ spaces covered with anti-aphid net in three of the four sides of the cages; the fourth side had a sliding door. The breeding cages were kept in the "Inoculated Insects" section, with temperature $25^{\circ} \mathrm{C}$, humidity $75 \%$ and controlled light conditions (10:14), irrigating the plants once a week.

\section{Entomopathogenic fungi}

The fungi $P$. fumosoroseus and $V$. lecanii were obtained from the Entomopathogenic Fungi collection of the PNCB Laboratory (Gómez et al., 2000). The main provenance characteristics are shown in Table 1. Twenty whitefly III and IV nymphs of the first generation bred in cages were caught at random, and the corresponding reactivation was done using 10 individuals for each of the two fungi species.

Once the nymphs were infected by the fungus, they were placed in a humid chamber to promote sporulation. After sporulation, a sample was taken with a pointed spreader, and the monoculture of each of the fungi was done using a Sabouraud dextrose agar medium (SDA) acidified at $25^{\circ} \mathrm{C}$, under permanent light. A concentration of $3 \times 10^{5}$ spores $\mathrm{mL}^{-1}$ was obtained from the original culture. Of this, $3 \mu \mathrm{L}$ were taken and deposited on the upper end of one of six lines previously marked on the back of the Petri dish, and the inoculum was spread upon those with the help of an inoculating loop. After incubation of the dish at $25^{\circ} \mathrm{C}$ during $24 \mathrm{~h}$, spore germination was observed using an optical microscope (Zeiss, B\#3 Reichert MicroStar 4, Hicksville, New York, USA) with 10X objective; later the area was marked using the $40 \mathrm{X}$ objective, and the agar block was cut with a scalpel, this was cultured in acidified SDA medium ( $1 \mathrm{~mL}$ lactic acid at $44 \%$ for each $100 \mathrm{~mL}$ ) and incubated at $25{ }^{\circ} \mathrm{C}$ under constant lighting. The storage of the fungi spores was done in $10 \%$ glycerol, temperature $-25^{\circ} \mathrm{C}$. The monoculture, collection and storage techniques were those developed by Estrada et al. (1997). The best resulting colony was propagated upon dishes and used as source for the assays.

\section{Election of the medium in which to establish the bioassays}

A preliminary test was carried out to determine the best bioassays medium. A humid chamber was prepared, placing leaves of approximately $2 \mathrm{~cm}^{2}$ infested with $A$. cocois nymphs, alternatively upon: 1) one cotton wetted with distilled water (TA), 2 cottons wetted with distilled water (2TA), or (3) upon agar-water $0.1 \%$ medium (TAG). Four replications of each treatment (TA, 2TA, TAG) and one control $(\mathrm{T})$ were done and placed in the chamber.

Table 1. Entomopathogenic fungi employed on bioassays with Aleurodicus cocois.

\begin{tabular}{llll}
\hline Entomopathogenic fungus & Code & \multicolumn{1}{c}{ Isolated from } & Crop \\
\hline Paecilomyces fumosoroseus & CCBLE-818 & Bemisia tabaci Gennadius, 1889 & Cotton \\
Verticillium lecanii & CCBLE-506 & Coccus hesperidum Linnaeus, 1758 & Grapefruit \\
\hline
\end{tabular}

Locality: Cañete, Lima, Peru. 


\section{Execution of the fungi and whiteflies bioassays}

Three treatments were applied to each stage (egg, nymph I, II, III and IV) of the pest, and one control, with four replications of 10 specimens each. Spores of the respective fungi were diluted down to a concentration of $10^{8}$ conidia $\mathrm{mL}^{-1}$; this was verified by means of direct counting of conidia as indicated by Gómez et al. (2000). The effective dose of entomopathogenic fungi spores applied upon $A$. cocois followed the indications of Alean (2003). Leaves infested with $A$. cocois were cut and separated according to the corresponding stage and the products were then applied.

The suspensions to be applied ( $200 \mathrm{~mL}$ each) were prepared in 1 and $1.5 \mathrm{~L}$ plastic bottles as follows: distilled water (control); solutions with conidia of each of the entomopathogenic fungi and one mixture of both treatments, each fungus bringing $50 \%$ of the total of spores, adding Tween $0.1 \%$ to the treatments and to the control. A nozzle was placed on each of the bottles, and the contents were sprayed upon the leaves with nymphs and/or eggs, according to the assigned treatments. The suspension volume sprayed in each treatment was $4.0 \pm 0.5 \mathrm{~mL}$. Finally, the leaves were placed upon the agar in the dishes, and remained under the same breeding conditions in the "Inoculated Insects" area. Evaluations were carried out by direct observation and with the help of a stereoscopic microscope (Zeiss, S\# 4 Olympus VM-1, Hicksville, New York, USA) at 1, 2 and 7 days for the eggs and nymph I, and at 4, 8 and 12 days for nymphs II to IV. The insects showing hifal growth were considered as killed by the fungus (Badilla et al., 1996; Gómez, 1999).

\section{Statistical analysis}

An ANOVA variance analysis was performed to determine the medium in which the essays would be carried out. An angular transform of the data was done, using the arc cosine of the square root of the mortality percentage before the analysis, to stabilize the variance error (Zar, 1996). Tukey's test ( $\mathrm{P}=$ $0.05)$ was performed when significant differences appeared among the treatments. The mortality percentages of the essays to determine the effect of the two entomopathogenic fungi upon the eggs and I to IV nymphs of $A$. cocois, were transformed to the arc cosine of the square root before the ANOVA and the Levine test (Zar, 1996). From the later it was determined that, in spite of the transformation, the data did not show normal distribution, therefore, the mortality percentages were subjected to the equivalent Kruskal Wallis non parametric test (Zar, 1996), comparing the data among treatments and among exposure periods for each stage. Descriptive and inferential statistical calculations were done using the SPSS 13.0 (SPSS, 2003) program. The Abbot formula was used in all cases where the mortality percentage of the control was different from zero (Abbot, 1925).

\section{RESULTS}

\section{Election of the medium to establish the bioassays} The A. cocois mortality percentage on agar-water plaques was $46.7 \%$; with two cottons of $70,5 \%$ and with one cotton of $86 \%$ (Table 2). The percentage of dead specimens on the agar-water medium was different from all others. The mortality percentage on the two other treatments was equal to the mortality percentage of the control; therefore it was decided to carry out the essays on the agar-water medium.

\section{Comparison among fungal treatments}

Eggs. All treatments showed the same pattern; there were no effects during the first days and high mortality percentages were reached on the seventh day, without differences between the fungi, either separated or mixed (Table 3 ).

Nymph I. All treatments produced initially some degree of mortality as compared to the control, although $V$. lecanii killed less specimens than the other two treatments. All the treatments produced high rates of mortality on the seventh day, with no differences among them (Table 3).

Table 2. Bioassay media election.

\begin{tabular}{cc}
\hline Culture media & Mortality (\%) \\
\hline T & $86.7 \mathrm{a}$ \\
TA & $73.99 \mathrm{a}$ \\
2TA & $70.5 \mathrm{a}$ \\
TAG & $46.6 \mathrm{~b}$ \\
\hline CV & 25.5 \\
\hline LSD & 0.56 \\
WD & 0.87 \\
\hline
\end{tabular}

Different letters on the same column indicate significant differences according to Tukey's test $(\mathrm{P} \leq 0.05)$.

$\mathrm{T}=$ control; $\mathrm{TA}$ : cotton humidified with distilled water; $2 \mathrm{TA}$ : two cottons humidified with distilled water; TAG: agar-water medium, $0.1 \%$; $\mathrm{CV}=$ variation coefficient; LSD: least significant diference; WD: Waller Duncan. 
Table 3. Comparative effect of Paecilomyces fumosoroseus and Verticillium lecanii on mortality (\%) of Aleurodicus cocois eggs and nymphs I-IV.

\begin{tabular}{|c|c|c|c|}
\hline \multirow[t]{2}{*}{ Treatment } & Mean \pm SD & Mean \pm SD & Mean \pm SD \\
\hline & 1 day & 2 days & 7 days \\
\hline \multicolumn{4}{|l|}{ Eggs } \\
\hline $\mathrm{T}$ & $0 \pm 0 \mathrm{a}$ & $0 \pm 0 \mathrm{a}$ & $0 \pm 21.6 \mathrm{a}$ \\
\hline $\mathrm{P}$ & $0 \pm 0 \mathrm{a}$ & $0 \pm 0 \mathrm{a}$ & $75 \pm 5.8 b$ \\
\hline V & $0 \pm 0 \mathrm{a}$ & $0 \pm 0 \mathrm{a}$ & $82.5 \pm 15 b$ \\
\hline PV & $0 \pm 0 \mathrm{a}$ & $0 \pm 0 \mathrm{a}$ & $77.5 \pm 5 b$ \\
\hline K-W value & NS & NS & 9.30 \\
\hline Sig. & NS & NS & 0.008 \\
\hline \multicolumn{4}{|l|}{ Nymph I } \\
\hline $\mathrm{T}$ & $0 \pm 0 \mathrm{a}$ & $0 \pm 0 \mathrm{a}$ & $0 \pm 20 \mathrm{a}$ \\
\hline $\mathrm{P}$ & $12.5 \pm 18.9 b$ & $20 \pm 18.3 b$ & $87.5 \pm 15 b$ \\
\hline $\mathrm{V}$ & $0 \pm 0 \mathrm{a}$ & $0 \pm 0 \mathrm{a}$ & $87.5 \pm 25 b$ \\
\hline PV & $12.5 \pm 5 b$ & $17.5 \pm 10 \mathrm{~b}$ & $72.5 \pm 21 b$ \\
\hline $\mathrm{K}$-W value & 9.80 & 10.65 & 10.08 \\
\hline Sig. & 0.005 & 0.002 & 0.004 \\
\hline Nymph II & 4 days & 8 days & 12 days \\
\hline $\mathrm{T}$ & $0 \pm 0 \mathrm{a}$ & $0 \pm 0 \mathrm{a}$ & $0 \pm 0 \mathrm{a}$ \\
\hline $\mathrm{P}$ & $15 \pm 19.1 b$ & $21.1 \pm 16.3 b c$ & $73.6 \pm 24.9 b$ \\
\hline $\mathrm{V}$ & $7.8 \pm 9.7 \mathrm{a}$ & $28.9 \pm 19.6 c$ & $97.2 \pm 5.6 \mathrm{c}$ \\
\hline PV & $0 \pm 0 \mathrm{a}$ & $10 \pm 8 b$ & $85.1 \pm 5 b$ \\
\hline $\mathrm{K}$-W value & 9.80 & 9.78 & 12.01 \\
\hline Sig. & 0.005 & 0.005 & 0.0005 \\
\hline \multicolumn{4}{|l|}{ Nymph III } \\
\hline $\mathrm{T}$ & $5.5 \pm 5 a$ & $0 \pm 0 \mathrm{a}$ & $0 \pm 0 \mathrm{a}$ \\
\hline $\mathrm{P}$ & $7.5 \pm 9.6 \mathrm{a}$ & $38.4 \pm 14.2 b$ & $50 \pm 57.7 b$ \\
\hline $\mathrm{V}$ & $15 \pm 10 \mathrm{ab}$ & $11.9 \pm 9.2 \mathrm{a}$ & $50 \pm 57.7 b$ \\
\hline PV & $25 \pm 12.9 b$ & $32.4 \pm 13 b$ & $50 \pm 57.7 b$ \\
\hline $\mathrm{K}-\mathrm{W}$ value & 7.34 & 11.75 & 3 \\
\hline Sig. & 0.03 & 0.0007 & 0.016 \\
\hline \multicolumn{4}{|l|}{ Nymph IV } \\
\hline $\mathrm{T}$ & $0 \pm 0 \mathrm{a}$ & $0 \pm 0 \mathrm{a}$ & $0 \pm 0 \mathrm{a}$ \\
\hline $\mathrm{P}$ & $0 \pm 0 \mathrm{a}$ & $15 \pm 23.8 \mathrm{ab}$ & $12.5 \pm 15 \mathrm{ab}$ \\
\hline $\mathrm{V}$ & $7.5 \pm 5 b$ & $20 \pm 11.5 b$ & $41.4 \pm 30.2 b$ \\
\hline PV & $0 \pm 0 \mathrm{a}$ & $12.5 \pm 19 \mathrm{ab}$ & $45.4 \pm 12 c$ \\
\hline $\mathrm{K}-\mathrm{W}$ value & 10.38 & 5.82 & 9.11 \\
\hline Sig. & 0.003 & 0.05 & 0.009 \\
\hline
\end{tabular}

Different letters on the same column indicate significant differences according to Tukey's test $(\mathrm{P} \leq 0.05)$. SD: Standard deviation; Sig.: significance; T: control; P: Paecilomyces fumosoroseus; V: Verticillium lecanii; PV: Paecilomyces fumosoroseus + Verticillium lecanii; K-W Value: Kruskal Wallis value; NS: not significant.

Nymph II. The effects could only be detected from the eight day onwards. At the end of the evaluation, the most effective treatment was that of $V$. lecanii and there were no differences among the rest of the treatments (Table 3).
Nymph III. The combined treatment was deadlier than the other two at the start (day 4), but the three treatments became equal on the $12^{\text {th }}$ day (Table 3 ). 
Nymph IV. There was no clear tendency in this stage. Initially (day 4) the best treatment was V. lecanii alone, but the three treatments became equal on the $8^{\text {th }}$ day, while towards the end (day 12 ), only the $V$. lecanii and combined treatment produced mortality, and the treatment with $P$. fumosoroseus showed no differences with the control (Table 3).

\section{Comparison among exposure times}

Concerning the exposure period, for the eggs the effect showed up on the $7^{\text {th }}$ day only, no effects were perceived on the $1^{\text {st }}$ and $2^{\text {nd }}$ days (Table 4 ). On the other hand, for Nymph I, all three treatments showed a significant effect on the seventh day. For Nymph II, the greatest effect of mortality due to fungi was registered on day 12 , and only for the mixture of entomopathogenic fungi were there effects on the eight day. Concerning Nymph III, the mortality percentage under the two fungi across time was similar, that is to say, were no variations in any of the cases. The same happened in the case of Nymph IV, except that there was a statistical difference in the case of combined fungi on day 12.

Table 4. Effect of Paecilomyces fumosoroseus and Verticillium lecanii on mortality (\%) of eggs and nymphs I-IV of Aleurodicus cocois in three periods of exposure.

\begin{tabular}{|c|c|c|c|c|}
\hline \multirow[t]{2}{*}{ Treatment } & Control & $\mathbf{P}$ & V & $\mathbf{P}+\mathbf{V}$ \\
\hline & Mean \pm SD & Mean \pm SD & Mean \pm SD & Mean \pm SD \\
\hline \multicolumn{5}{|l|}{ Eggs } \\
\hline $1 \mathrm{~d}$ & $0 \pm 0 \mathrm{a}$ & $0 \pm 0 \mathrm{a}$ & $0 \pm 0 \mathrm{a}$ & $0 \pm 0 \mathrm{a}$ \\
\hline $2 d$ & $0 \pm 0 \mathrm{a}$ & $0 \pm 0 \mathrm{a}$ & $0 \pm 0 \mathrm{a}$ & $0 \pm 0 \mathrm{a}$ \\
\hline $7 \mathrm{~d}$ & $30 \pm 21.6 b$ & $75 \pm 5.8 b$ & $82.5 \pm 15 b$ & $77.5 \pm 5 b$ \\
\hline $\mathrm{K}-\mathrm{W}$ value & 10.46 & 10.56 & 10.51 & 10.67 \\
\hline Sig. & 0.005 & 0.005 & 0.005 & 0.005 \\
\hline \multicolumn{5}{|l|}{ Nymph I } \\
\hline $1 \mathrm{~d}$ & $0 \pm 0 \mathrm{a}$ & $12.5 \pm 18.9 \mathrm{a}$ & $0 \pm 0 \mathrm{a}$ & $12.5 \pm 50 \mathrm{a}$ \\
\hline $2 \mathrm{~d}$ & $0 \pm 0 \mathrm{a}$ & $20 \pm 18.3 \mathrm{a}$ & $0 \pm 0 \mathrm{a}$ & $17.5 \pm 10 \mathrm{a}$ \\
\hline $7 \mathrm{~d}$ & $10 \pm 20 a$ & $87.5 \pm 15 b$ & $87.5 \pm 25 b$ & $72.5 \pm 21 b$ \\
\hline $\mathrm{K}-\mathrm{W}$ value & 2 & 7.72 & 10.67 & 8.26 \\
\hline Sig. & 0.36 & 0.02 & 0.005 & 0.01 \\
\hline \multicolumn{5}{|l|}{ Nymph II } \\
\hline $4 d$ & $0 \pm 0 \mathrm{a}$ & $15 \pm 19.1 \mathrm{a}$ & $7.8 \pm 9.7 \mathrm{a}$ & $0 \pm 0 \mathrm{a}$ \\
\hline $8 \mathrm{~d}$ & $0 \pm 0 \mathrm{a}$ & $21.1 \pm 16.3 \mathrm{a}$ & $28.9 \pm 19.6 \mathrm{a}$ & $10 \pm 8 b$ \\
\hline $12 \mathrm{~d}$ & $0 \pm 0 \mathrm{a}$ & $73.6 \pm 24.9 b$ & $97.2 \pm 5.6 b$ & $85.1 \pm 5 c$ \\
\hline $\mathrm{K}-\mathrm{W}$ value & NS & 7.32 & 8.73 & 9.60 \\
\hline Sig. & NS & 0.02 & 0.01 & 0.008 \\
\hline \multicolumn{5}{|l|}{ Nymph III } \\
\hline $4 \mathrm{~d}$ & $2.5 \pm 5 \mathrm{a}$ & $7.5 \pm 9.6 \mathrm{a}$ & $15 \pm 10 \mathrm{a}$ & $25 \pm 13 a$ \\
\hline $8 \mathrm{~d}$ & $0 \pm 0 \mathrm{a}$ & $38.4 \pm 14.2 \mathrm{a}$ & $11.9 \pm 9.2 \mathrm{a}$ & $32.4 \pm 13 a$ \\
\hline $12 \mathrm{~d}$ & $0 \pm 0 \mathrm{a}$ & $50 \pm 57.7 \mathrm{a}$ & $50 \pm 57.7 \mathrm{a}$ & $50 \pm 58 \mathrm{a}$ \\
\hline $\mathrm{K}-\mathrm{W}$ value & 8.28 & 3.36 & 0.21 & 0.34 \\
\hline Sig. & 0.06 & 0.18 & 0.89 & 0.84 \\
\hline \multicolumn{5}{|l|}{ Nymph IV } \\
\hline $4 d$ & $0 \pm 0 \mathrm{a}$ & $0 \pm 0 \mathrm{a}$ & $5.8 \pm 5 \mathrm{a}$ & $0 \pm 0 \mathrm{a}$ \\
\hline $8 \mathrm{~d}$ & $0 \pm 0 \mathrm{a}$ & $15 \pm 23.8 \mathrm{a}$ & $20 \pm 11.5 \mathrm{a}$ & $12.5 \pm 19 a$ \\
\hline $12 \mathrm{~d}$ & $0 \pm 0 \mathrm{a}$ & $12.5 \pm 15 \mathrm{a}$ & $41.4 \pm 30.2 \mathrm{a}$ & $45.4 \pm 12 b$ \\
\hline $\mathrm{K}-\mathrm{W}$ value & NS & 2.61 & 3.40 & 8.28 \\
\hline Sig. & NS & 0.27 & 0.18 & 0.01 \\
\hline
\end{tabular}

Different letters on the same column indicate significant differences according to Tukey's test ( $\leq \leq 0.05)$.

SD: Standard deviation; Sig.: significance; T: Control; P: Paecilomyces fumosoroseus; V: Verticillium lecanii; P+V: Paecilomyces fumosoroseus + Verticillium lecanii; K-W Value: Kruskall-Wallis Value; NS: not significant. 


\section{Global analysis}

In the nymph I and nymph II stages, mortality appeared during the first days with the application of de $P$. fumosoroseus, while $V$. lecanii had less effect on the specimens, but this changed for the nymph III and nymph IV stages. This could be due that the first and second instar nymphs are more susceptible at the beginning to P. fumosoroseus than the nymph II and nymph IV stages, but that in time $V$. lecanii causes a higher mortality in nymph I and nymph II. The only stage where a significant percentage of development of the mixture of the two fungi was nymph IV (Tables 3 and 4).

\section{DISCUSSION}

The developmental stage of the whitefly influences its susceptibility to infection, as the pathogen does not affect it equally in all its stages (Torres and Cárdenas, 1996). V. lecanii infested B. tabaci in the nymph period, especially the nymph II stage (Shannon, 1996), but does not affect the pupae, adults nor eggs. Candido (1999) stated that the susceptibility of $B$. tabaci to $P$. fumosoroseus is very low. However, some P. fumosoroseus lines infest the nymphs, pupae and adults of this insect (Torres and Cárdenas, 1996).

Ramos et al. (2000) mention a mortality of $37.7 \%$ on the eggs of $B$. tabaci on the 8th day after the application of $B$. bassiana. On the other hand, it has been found that the control of $T$. vaporarium eggs with Aschersonia aleyrodis Webber, 1897 (Fransen et al., 1987) was not efficient, and neither with $V$. lecanii (Fransen, 1990). For this reason at 1 and 2 days from infection no symptoms were detected on the eggs (Table 3). Generally speaking, for these two exposure periods, the mortality percentages of the eggs was lower than that appreciated in the nymph I and nymph II stages, this could be due to the physical barriers belonging to the corium (Ramos et al., 2000), and that the proteases produced by the entomopathogenic fungi would not have initially the same effect on the corium of the eggs than on the cuticle of the insect nymphs (Badilla et al., 1996). However, the Kruskal Wallis test for the eggs and for the nymph I stage of $A$. cocois shows significant effects of the three treatments at 7 days after the exposure (Table 3 ).

B. bassiana showed effectiveness between 78.2 and $89.5 \%$ on the $8^{\text {th }}$ day, for the control of the first in- star nymphs of B. tabaci (Ramos et al., 2000). These percentages are within the range obtained in this study for $A$. cocois on the $7^{\text {th }}$ day of exposure. Similarly, B. bassiana showed effectiveness between 79 and $95 \%$ for the control of $A$. floccosus eggs and nymphs of $A$. floccosus in laboratory conditions (Santamaría et al., 1998).

Morales and Cardona (1996) determined that the first nymph stages of $T$. vaporariorum and $B$. taba$c i$ are the most susceptible to entomopathogenic fungi, and this resembles the present results. On the other hand, Sánchez and Belloti (1997) state that the second instar of Aleurotrachelus socialis bordalis Bondar is the stage most susceptible to $B$. bassiana. This shows the high susceptibility to entomopathogenic fungus of this stage.

Osborne et al. (1990) affirm that the third nymph instar is less susceptible to infection that the second, this also supports the results obtained (Table 3). According to Gómez (1999), V. lecanii is the most effective pathogen upon A. cocois, in laboratory as well as in greenhouse and field conditions However, according to Alean (2003), the A. socialis nymph III shows the highest mortality percentages for $V$. lecanii.

Using one application of $V$. lecanii on A. socialis, Alean (2003) obtained a $82.5 \%$ mortality of the eggs, and of $58.5 \%$ for the third instar nymphs, very similar to the results obtained on this study, but differed from the results observed for nymphs I, II and IV in $A$. cocois, because the mortality percentage of $A$. socialis in each stage was nymph I: $60.4 \%$; nymph II: $72 \%$; and nymph IV: $61.5 \%$.

At the beginning there was low mortality effect on $A$. cocois nymphs I and II by $V$. lecanii, this changed from nymph III to nymph IV (Table 3 ); therefore the nymph I and II stages would be more susceptible to P. fumosoroseus at the beginning as compared to nymphs III and IV. But $V$. lecanii caused a higher mortality in nymphs I and II (Table 4). Vidal et al. (1997) demonstrated that $P$. fumosoroseus is highly pathogenic for $B$. argentifolii instar II, between days 5 and 7, and Landa et al. (1994) registered that $P$. fumosoroseus can develop very rapidly both upon $B$. argentifolii and $T$. vaporariorum.

Badilla et al. (1996) show that in the nymph IV stage of $B$. tabaci the effectiveness percentage can 
reach $100 \%$ for $P$. fumosoroseus and $91 \%$ for $V$. lecanii at $20{ }^{\circ} \mathrm{C}$; on the contrary at $25{ }^{\circ} \mathrm{C}$ (temperature of the present experiment) it can be slightly less, up to $89.3 \%$ for P. fumosoroseus and $91.2 \%$ for $V$. lecanii. These results would explain the higher mortality percentage observed for $V$. lecanii on nymph IV as compared to $P$. fumosoroseus (Table $3)$.

The synergic effect observed on many occasions for the combined action of different entomopathogenic organisms for the control of insect pests (Glare and O'Callaghan, 2000; Cloyd, 2001; Solter and Wraight, 2001; Zurek et al., 2002) was not observed in the present study. Generally speaking, the combined treatment of $P$. fumosoroseus and $V$. lecanii did not produce a higher mortality percentage upon A. cocois eggs and nymphs than the separate treatments (Table 3 ). Therefore, it is not considered convenient nor economical to use a combination of these two entomopathogenic fungi for the control of A. cocois, as it has been demonstrated that, except for a slight increment of the effect of both fungi upon nymph IV, the combined control is no more effective, in any other development stage, than the use of both fungi separately.

\section{CONCLUSIONS}

The effect of the entomopathogenic fungi alone or combined is similar for the control of the A. cocois eggs, nymphs I and III. But there is an increase of the effect of $P$. fumosoroseus upon nymph I on the second day. The effect of $V$. lecanii upon the second nymph stage of $A$. cocois was better than that of $P$. fumosoroseus and that of the fungi mixture, since the highest mortality percentage occurred from the eight to the twelfth day. Only in the case of the IV nymph stage was there a slight increment of the effect when combining the two entomopathogenic fungi.

\section{Efecto de dos hongos entomopatógenos en el control de Aleurodicus cocois (Curtis, 1846) (Hemiptera: Aleyrodidae)}

\author{
R E S U M E N
}

Aleurodicus cocois (Curtis, 1846), la mosca blanca del cocotero, constituye una plaga muy importante en el Perú, principalmente en el palto (Persea americana Mill.). Se ha determinado que los hongos entomopatógenos pueden infectar y matar a la mosca blanca, por lo que podrían ser usados como agentes de control biológico. El objetivo del presente trabajo fue determinar si existe alguna acción conjunta de dos hongos entomopatógenos Paecilomyces fumosoroseus (Wize) Brown \& Smith 1957 y Verticillium lecanii (Zimmerman, 1892) Viégas 1939, en el control de A. cocois. Para ello se prepararon previamente placas de plástico estériles en las que se sirvieron aproximadamente $5 \mathrm{~mL}$ de agar al $2 \%$, donde se colocaron hojas infestadas con A. cocois, aplicándose tres tratamientos por aspersión: P. fumosoroseus $(\mathrm{P})$, V. lecanii $(\mathrm{V})$ y la mezcla de los dos hongos, los cuales se evaluaron en el caso de Ninfa I y huevos después de uno, dos y siete días, y para las Ninfas II, NIII y NIV cada cuatro, ocho y 12 días. El efecto de mortalidad de $V$. lecanii sobre el segundo estadío ninfal de $A$. cocois fue mejor que $P$. fumosoroseus y que la mezcla de ambos hongos, ya que el mayor porcentaje de mortalidad se presentó desde el octavo día hasta el día 12. En el caso del IV estadío ninfal se observó un ligero incremento en el efecto al combinarse los dos hongos entomopatógenos evaluados, siendo menor el efecto en P. fumosoroseus.

Palabras clave: control biológico, mosca blanca, Paecilomyces, plagas, Verticillium. 


\section{LITERATURE CITED}

Abbott, W. S. 1925. A method for computing the effectiveness of an insecticide. J. Econ. Entomol. 18:265-267.

Alean, I. 2003. Evaluación de la patogenicidad de diferentes hongos entomopatógenos para el control de la mosca blanca de la yuca Aleurotrachelus socialis Bondar (Homoptera: Aleyrodidae) bajo condiciones de invernadero. 107 p. Tesis Microbiología Agrícola y Veterinaria. Pontificia Universidad Javeriana, Facultad de Ciencias Básicas, Microbiología Agrícola y Veterinaria, Bogotá, Colombia.

Badilla, F., J.C. Toledo, y C. Barreno. 1996. Patogenicidad de Metarhizium anisopliae en adultos de la "chinche salivosa" Aeneolamia albofasciata y Prosapia spp. (Homoptera: Cercopidae) en la caña de azúcar en Escuintla, Guatemala. Manejo Integrado de Plagas 42:39-44.

Blatta, S. 2001. La mosca blanca del tabaco Bemisia tabaci (Gennadius, 1889) (Hemiptera: Leyrodidae) II. Enemigos naturales. Rev. Terralia on line. Disponible en http://www.terralia.com/revista23/ pagina56.asp Leído el 29 de diciembre de 2003.

Candido, G. 1999. Virulence of the entomopathogenic fungus Paecilomyces amoenerosues (Hennigs) Samson toward the whitefly Bemisia argentifolii Belows and Perring. 100 p. Thesis MSc. University of California, Riverside, California, USA.

Cloyd, R. 2001. The dilemma of tank-mixing. Greenhouse Manage. Prod. 21:66-67.

Duke, J. 1983. Handbook of energy crops. On line. Available at http://www.hort.purdue.edu/newcrop/ duke energy/dukeindex.html Accessed 29 December de 2003.

Estrada, V., A. Vélez, y N. López. 1997. Estandarización de una metodología para obtener cultivos monoespóricos del hongo Beauveria bassiana. Cenicafé 48:559-565.

Evans, G.A. 2007. The whiteflies (Hemiptera: Aleyrodidae) of the world and their host plants and natural enemies. 715 p. USDA/Animal Plant Health Inspection Service (APHIS), Riverdale, Maryland, USA.

Fransen, J. 1990. Natural enemies of whiteflies: Fungi. p. 187-211. In Gerling, D. (ed.) Whiteflies: their bionomics, pest status and management. Intercept, Wimborne, UK.

Fransen, J., K. Winkelman, and J.C. Van Lenteren. 1987. The differential mortality at various life stages of the greenhouse whitefly. Trialeurodes vaporariorum (Homoptera: Aleyrodidae), by infection with the fungus Aschersonia aleyrodis (Deuteromycosina: Coelomycetes). J. Invertebr. Pathol. 50:158-165.
García, J., y A. López. 1997. Evaluación de cepas nativas de Verticillium lecanii (Zimm.) Viégas en el control de la mosca blanca de los invernaderos Trialeurodes vaporatiorum (Westwood). Rev. Colomb. Entomol. 23:25-30.

Glare, T., and M. O'Callaghan. 2000. Bacillus thuringiensis: Biology, ecology and safety. 350 p. John Wiley \& Sons, New York, USA.

Gómez, H. 1999. Aislamiento e identificación de hongos entomopatógenos de la "mosca blanca" Bemisia tabaci (Gennadius) (Homoptera: Aleyrodidae) en Lima, Perú. Rev. Per. Entomol. 41:83-86.

Gómez, H., A. Zapata, y H. Gamarra. 2000. Producción de hongos y virus entomopatógenos para el control de plagas agrícolas. 44 p. Servicio Nacional de Sanidad Agraria (SENASA), Lima, Perú.

Landa, Z., L. Osborne, F. López, and J. Eyal. 1994. A bioassay for determining pathogenicity of entomogenous fungi on whiteflies. Biol. Control 4:341-350.

Liceras, L.Z., y J.C. Clemente. 2006. Plagas insectiles en el cultivo de lúcumo Pouteria lucuma [R. et P.] O. Kze., en la Provincia de Trujillo, La Libertad. Pueblo Cont. (Perú) 17:5-10.

Morales, A., y C. Cardona. 1996. Evaluación de diferentes hongos entomopatógenos sobre las moscas blancas Bemisia tabaci y Trialeurodes vaporariorum. $21 \mathrm{p}$. Informe final. Convenio CIAT-Agrevo S.A. Centro Internacional de Agricultura Tropical (CIAT), Palmira, Colombia.

Morton, J. 1987. Biriba. p. 88-90. In J. Morton (ed.) Fruits of warm climates. Creative Resource Systems. Miami, Florida, USA.

Núñez, E. 1995. Reporte de Perú. In R. Caballero and A. Pitty (eds.) In Memoria, IV Taller Latinoamericano sobre moscas blancas y geminivirus, Zamorano. 1618 Octubre, 1995. Zamorano, Honduras. CEIBA $36: 157-162$.

Núñez, E. 1998. Los Aleyrodidae peruanos y sus controladores biológicos. p. 5. In XL Convención Nacional de Entomología, Ica. Noviembre de 1998. Sociedad Entomológica del Perú, Lima, Perú.

Núñez, E. 2000. Las moscas blancas y sus enemigos naturales. p. 53. In XLII Convención Nacional de Entomología, Lima. Noviembre de 1998. Sociedad Entomológica del Perú, Lima, Perú.

Osborne, L., K. Hoelmer, and D. Gerling. 1990. Prospects for biological control of Bemisia tabaci. International Organization for Biological Control/West Paleartic Regional Section (IOBC/WPRS) Bulletin 13:153-160.

Ramos, E., S. Alves, M.R. Tanzini, y R.B. Lópes. 2000. Susceptibilidad de Bemisia tabaci a Beauveria bassiana en condiciones de laboratorio. Manejo Integrado de Plagas (Costa Rica) 56:65-69. 
Reátegui, A., y E. Núñez. 1998. Niveles de infestación de Aleurodicus cocois (Curtis) en tres hospederos botánicos. p. 78. In XL Convención Nacional de Entomología, Lima. Noviembre de 1998. Sociedad Entomológica del Perú, Lima, Perú.

Rodríguez Dos Santos, A., y E. Del Pozo Núñez. 2003. Aislamiento de hongos entomopatógenos en Uruguay y su virulencia sobre Trialeurodes vaporariorum West. Agrociencia (Cuba) 2:71-78.

Sánchez, D., y A. Bellotti. 1997. Evaluación de la patogenicidad de hongos Hypomycetes sobre la mosca blanca de la yuca Aleurotrachelus socialis. 21 p. Informe final. Convenio Cooperativo CIATCOLCIENCIAS. Centro Internacional de Agricultura Tropical (CIAT), Palmira, Colombia.

Santamaría, A., J. Costa-Comelles, A. Alonso, J.M. Rodríguez, y J. Ferrer. 1998. Ensayo del hongo entomopatógeno Beauveria bassiana (Bálsamo) Vuillemin para el control de la mosca blanca de los cítricos Aleurothrixus floccosus (Maskell) (Homoptera: Aleyrodidae) y su acción sobre el parásito Cales noacki (Howard) (Hymenoptera: Aphelinidae). Bol. San. Veg. Plagas 24:695-706.

Shannon, P. 1996. Hongos entomopatógenos. p. 60-68. In L. Hilje (ed.) Metodologías para el estudio y manejo de moscas blancas y geminivirus. Serie de Materiales $\mathrm{N}^{\circ}$ 37. Centro Agronómico de Investigación y Enseñanza (CATIE), Turrialba, Costa Rica.

Solter, L., and S. Wraight. 2001. Development, evaluation and safety of entomopathogens for leaf feeding insect defoliators. 301 p. Annual Report of Multi-State Project, Urbana, Illinois, USA.

Soto, A., y F. García. 2002. Especies de moscas blancas en los cítricos de España Peninsular. Las moscas blancas de cítricos. On line. Disponible en http:// www.seea.es/conlupa/mbcitricos/mbCitricos 4 .htm Leído el 29 de diciembre de 2003.
SPSS. 2003. Statistical package for the social sciences. Base 12.0 user's guide. 368 p. SPSS Inc., Chicago, Illinois, USA.

Torres, E., y H. Cárdenas. 1996. Paecilomyces fumosoroseus (Wize) Brown \& Smith en el control microbiano de la mosquita blanca Bemisia argentifolii Bellows \& Perring (Homoptera: Aleyrodidae). p. 40. In XIX Congreso Nacional de Control Biológico. Simposium de Control Biológico de Mosquita Blanca. Culiacán, 14-15 de noviembre. Sociedad Mexicana de Control Biológico, Culiacán, Sinaloa, México.

Valencia, L. 2000. La mosca blanca en la agricultura peruana. 20 p. Industria Gráfica Cimagraf, Lima, Perú.

Valencia, L., N. Mujica, y F. Cisneros. 2000. Las moscas blancas y sus enemigos naturales. Informe de Perú. p. 62. In L. Hilje (ed.) In IX Taller Latinoamericano y del Caribe sobre Moscas Blancas y Geminivirus. Panamá, 22-24 de noviembre. Instituto de Investigación Agropecuaria de Panamá, Panamá, República de Panamá.

Vidal, C., L.A. Lacey, and J. Fargues. 1997. Pathogenicity of Paecilomyces fumosoroseus (Deuteromycotina: Hypomycetes) against Bemisia argentifolii (Homoptera: Aleyrodidae) with a description of a bioassay method. J. Econ. Entomol. 90:765-772.

Zar, J. 1996. Biostatistical analysis. 662 p. $3^{\text {rd }}$ ed. Prentice Hall Upper, Saddle River, New Jersey, USA.

Zurek, L., W. Watson, and C. Schal. 2002. Synergism between Metarhizium anisopliae (Deuteromycota: Hyphomycetes) and boric acid against the German cockroach (Dictyoptera: Blattellidae). Biol. Control 23:296-302. 